\title{
Cost of Production for Fresh Market Grapefruit Grown in Indian River, 2020/21
}

\author{
Ariel Singerman ${ }^{2}$
}

This publication presents the cost of production per acre for growing fresh grapefruit in the Indian River Citrus District during 2020/21. The data were collected during a virtual Production Committee meeting of the Indian River Citrus League in March 2021. During the meeting, each grower used a computer as a "clicker" or remote device to enter the costs for each caretaking program. Collecting the data in this way ensured that the process was anonymous and confidential. Surveying a panel of growers to obtain the costs of their production programs allows estimates that closely reflect growers' costs and cultural practices. This is particularly important because, since Huanglongbing (HLB, citrus greening) was found, growers have been modifying their practices from year to year in an attempt to cope with the disease. However, the cost estimates below do not represent any individual operation. Instead, their purpose is to serve as a benchmark for the Florida citrus industry. Typical users of these estimates include growers, consultants, property appraisers, and researchers.

The number of acres managed by the combined operations of the sample of participating growers accounted for approximately 8,950 acres, representing $56 \%$ of the acreage devoted to grapefruit in Indian River, which was estimated at 15,870 (USDA-NASS 2021). The questionnaire asked growers to provide annual, per-acre costs by program for a "typical" irrigated, mature grapefruit grove (10+ years old) with fruit marketed to the fresh market, including costs related to their tree replacement program. The figures below were obtained by computing the weighted average of the responses by the acreage of each of the growers.

Table 1 shows the cultural costs of production by program. Such estimates include both the costs of materials and their application. From Table 1, the total for weed management, which includes chemical and mechanical mowing as well as herbicides, was $\$ 258.48$ per acre. At $\$ 1,176.75$ per acre, foliar sprays represented the largest production cost. Fertilizer was the second largest expense at $\$ 535.50$ per acre. The expense for pruning was $\$ 122.50$ per acre, while that for irrigation was $\$ 169.11$ per acre. The cost per acre of canker control was $\$ 25.00$ and that of sub-contracted labor $\$ 47.50$. Adding all the costs listed above, the cultural cost of growing fresh grapefruit in the Indian River during 2020/21 without tree replacement was $\$ 2,334.84$ per acre.

Growers were also asked to provide details regarding their reset practices, including the number of trees replaced in their groves. On average, growers replaced three trees per acre during 2020/21. The total cost of tree replacement, including tree removal, site preparation, and care of those young trees, was estimated at $\$ 105.58$ per acre. Adding such a figure to the total cost above yields a total production cost with tree replacement of $\$ 2,440.42$ per acre.

Figure 1 depicts a double pie chart. The larger pie shows the cost of each program as well as the percentage relative to the cultural production costs with tree replacement. The

1. This document is FE1112, one of a series of the Food and Resource Economics Department, UF/IFAS Extension. Original publication date February 2022. Visit the EDIS website at https://edis.ifas.ufl.edu for the currently supported version of this publication.

2. Ariel Singerman, associate professor and Extension economist, Food and Resource Economics Department; UF/IFAS Citrus Research and Education Center, Lake Alfred, FL 32850.

The Institute of Food and Agricultural Sciences (IFAS) is an Equal Opportunity Institution authorized to provide research, educational information and other services

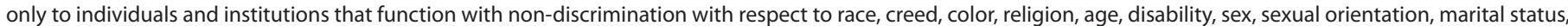

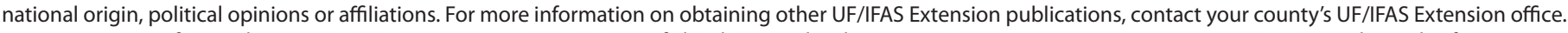
U.S. Department of Agriculture, UF/IFAS Extension Service, University of Florida, IFAS, Florida A \& M University Cooperative Extension Program, and Boards of County Commissioners Cooperating. Andra Johnson, dean for UF/IFAS Extension. 
smaller pie in Figure 1 provides greater detail regarding the individual components included in foliar sprays. Insecticides accounted for $\$ 246$ per acre and represented $10 \%$ of the cultural cost of production; fungicides accounted for $\$ 251$ per acre (10\%); foliar nutritionals for $\$ 169$ per acre (7\%); bactericides for $\$ 31$ per acre (1\%); aerial application for $\$ 6$ per acre $(0.2 \%)$; ground application of materials for $\$ 381$ per acre (16\%); biostimulants $\$ 33.75$ per acre (1\%); and adjuvants $\$ 60$ per acre (3\%).
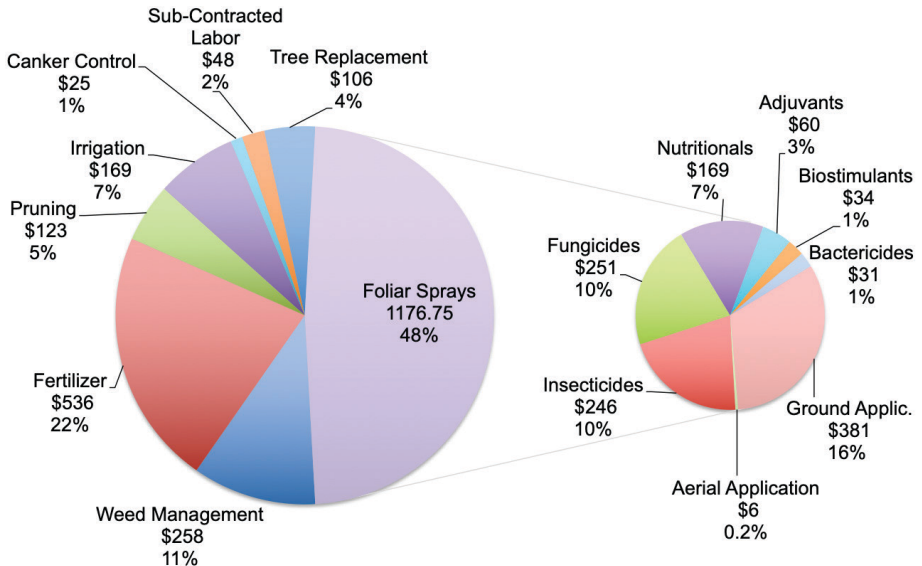

Figure 1. Cultural Costs of Production (in dollars per acre) for Fresh Market Grapefruit Grown in Indian River, Florida, 2020/21.

Credits: undefined

The main changes in cultural practices compared to 2018/19 (the last season for which estimates were available) are as follows. First, there was a decrease in nutritionals spending by $\$ 55$ per acre, on average. Second, growers reported spending, on average, $\$ 47$ per acre less on fertilizer than in 2018/19. Third, on average, growers spent $\$ 45$ per acre less on irrigation, tree replacement, and foliar applications. Figure 2 shows a comparison of the cost of the caretaking programs in 2020/21 relative to 2018/19.

In addition to cultural costs, growers typically have to incur in other costs when managing their groves; those costs include management, regulatory, and opportunity costs, which in 2020/21 accounted for $\$ 559.04$ per acre. Thus, table 2 shows the estimated total cost of production for fresh grapefruit growers in Indian River during 2020/21 was $\$ 2,999.46$ per acre. Based on this estimate, the breakeven prices per box for different levels of yield are presented in Table 3. Break-even prices were calculated on an on-tree and delivered-in basis. The later assumes harvesting costs per box for fresh grapefruit were $\$ 2.92$. The calculations in Table 3 also include the Florida Department of Citrus (FDOC) assessment of $\$ 0.07$ per box for grapefruit. Thus, for example, the on-tree and delivered-in break-even prices for covering the total costs of production with yield at 300 boxes per acre were $\$ 14.20$ and $\$ 16.54$ per box, respectively.

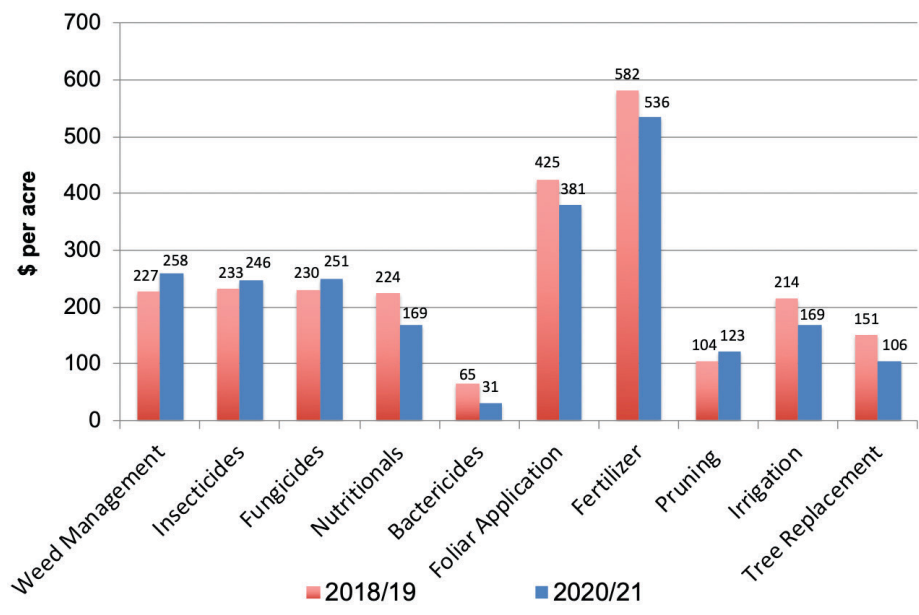

Figure 2. Cost of Production by Program for Fresh Market Grapefruit Grown in Indian River, Florida, 2020/21 vs. 2018/19.

Credits: undefined

\section{Summary}

This publication presents a summary of the costs of production for fresh market grapefruit grown in the Indian River Citrus District during 2020/21. The methodology chosen to collect the data consisted of surveying growers directly to closely reflect growers' costs in the era of HLB. The main changes this season were the cutbacks growers made on nutritionals, fertilizer, and tree replacement. The total cost of production for fresh grapefruit in Indian River during 2020/21 was $\$ 2,999.46$ per acre. Typical users of the estimates presented herein include growers and consultants, who use them as a benchmark; property appraisers, who use them to compute the taxes for property owners; and researchers, who use the estimates to evaluate the economic feasibility of potential new technologies.

\section{Reference}

USDA-NASS. 2020. Florida Citrus Statistics 2018/19. 
Table 1. Cultural Costs of Production per Acre for Fresh Market Grapefruit Grown in Indian River, Florida, 2020/21.

\begin{tabular}{|c|c|c|c|c|c|c|}
\hline \multicolumn{3}{|c|}{$\begin{array}{l}\text { Costs represent a mature grove } \\
(10+\text { years old) including resets }\end{array}$} & $\begin{array}{l}\text { Number of } \\
\text { Applications }\end{array}$ & $\begin{array}{l}\text { Materials Cost } \\
\text { per acre (\$) }\end{array}$ & $\begin{array}{l}\text { Application Cost } \\
\text { per acre (\$) }\end{array}$ & $\begin{array}{l}\text { Total Cost per } \\
\text { acre }(\$)\end{array}$ \\
\hline \multicolumn{7}{|c|}{ Production/Cultural Costs } \\
\hline \multicolumn{7}{|c|}{$\underline{\text { Weed Management }}$} \\
\hline & \multicolumn{2}{|c|}{ Mowing (Chemical \& mechanical) } & 7 & 7.49 & 82.56 & 90.05 \\
\hline & \multicolumn{2}{|l|}{ Herbicides } & 5 & 92.40 & 76.03 & 168.43 \\
\hline \multicolumn{3}{|c|}{ Total Weed Management Costs } & & & & 258.48 \\
\hline \multicolumn{7}{|l|}{$\underline{\text { Foliar Sprays }}$} \\
\hline & \multicolumn{2}{|l|}{ Insecticides } & & 246.25 & & 246.25 \\
\hline & \multicolumn{2}{|l|}{ Fungicides } & & 250.50 & & 250.50 \\
\hline & \multicolumn{2}{|l|}{ Nutritionals } & & 169.25 & & 169.25 \\
\hline & \multicolumn{2}{|l|}{ Adjuvants } & & 60.25 & & 60.25 \\
\hline & \multicolumn{2}{|l|}{ Biostimulants } & & 33.75 & & 33.75 \\
\hline & \multicolumn{2}{|l|}{ Bactericides } & & 30.75 & & 30.75 \\
\hline & \multicolumn{2}{|l|}{ Application: } & & & & \\
\hline & & Ground & 11 & & 380.50 & 380.50 \\
\hline & & Aerial & 1 & & 5.50 & 5.50 \\
\hline \multicolumn{6}{|c|}{ Total Foliar Sprays Costs } & $1,176.75$ \\
\hline \multicolumn{7}{|l|}{ Fertilizer } \\
\hline & \multicolumn{2}{|c|}{ Ground/Dry Fertilizer } & 4 & 274.50 & 38.25 & 312.75 \\
\hline & \multicolumn{2}{|c|}{ Fertigation/Liquid Fertilizer } & 17 & 201.00 & 21.75 & 222.75 \\
\hline \multicolumn{6}{|c|}{ Total Fertilizer Costs } & 535.50 \\
\hline \multicolumn{7}{|l|}{ Pruning } \\
\hline & \multicolumn{2}{|c|}{ Topping, Hedging, \& Skirting } & 1 & & 122.50 & 122.50 \\
\hline \multicolumn{6}{|c|}{ Total Pruning Costs } & 122.50 \\
\hline \multicolumn{7}{|l|}{ Irrigation } \\
\hline & \multicolumn{2}{|l|}{ Irrigation System ${ }^{1}$} & & & & 124.02 \\
\hline & \multicolumn{2}{|l|}{ Fuel for pump } & & & & 45.08 \\
\hline \multicolumn{6}{|c|}{ Total Irrigation Costs } & 169.11 \\
\hline \multicolumn{6}{|c|}{ Canker Control Costs ${ }^{2}$} & 25.00 \\
\hline Grove Sub-contra & ted Labor & & & & & 47.50 \\
\hline Total Production & Cultural Costs with & ut Tree Replac & & & & $2,334.84$ \\
\hline$\underline{\text { Tree Replacemen }}$ & 2 trees): & & & & & \\
\hline & Tree Removal (Clip & shear; use fron & loader) & & & 17.26 \\
\hline & Site Preparation ar & d Plant Tree (In & s reset trees) & & & 22.98 \\
\hline & Supplemental Fert & lizer, Sprays, Sp & etc. (Trees 1-3 year & ld) & & 65.33 \\
\hline Total Tree Replace & nent Costs & & & & & 105.58 \\
\hline Total Production & Cultural Costs with & Iree Replacem & & & & $2,440.42$ \\
\hline
\end{tabular}


Table 2. Total Costs of Production per Acre for Fresh Market Grapefruit Grown in Indian River, Florida, 2020/21.

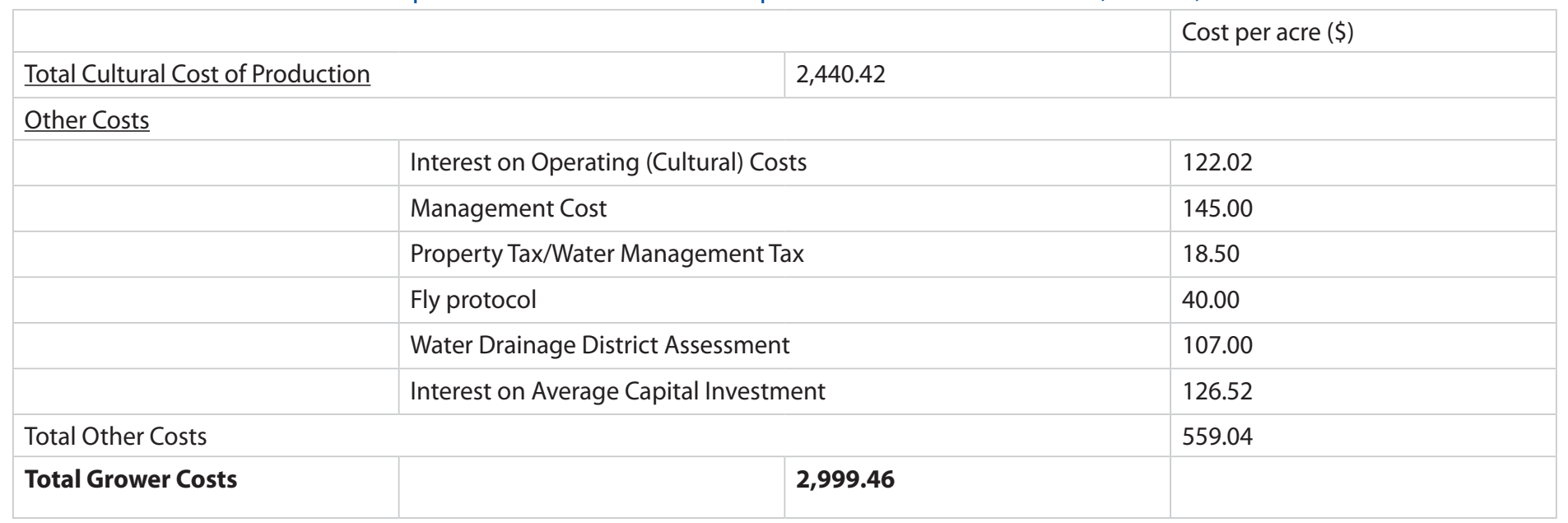

Table 3. Break-Even Price per Box for Fresh Market Grapefruit Grown in Indian River, Florida, 2020/21.

\begin{tabular}{|c|c|c|c|c|c|c|c|c|c|}
\hline & 175 & 200 & 225 & 250 & 275 & 300 & 325 & 350 & 375 \\
\hline & \multicolumn{9}{|c|}{ dollars per acre } \\
\hline $\begin{array}{l}\text { Cost of } \\
\text { production } \\
\text { per acre }\end{array}$ & 2999 & 2999 & 2999 & 2999 & 2999 & 2999 & 2999 & 2999 & 2999 \\
\hline $\begin{array}{l}\text { Pick and } \\
\text { Haul }\end{array}$ & 520 & 595 & 669 & 744 & 818 & 892 & 967 & 1041 & 1115 \\
\hline $\begin{array}{l}\text { FDOC } \\
\text { assessment } \\
(\$ 0.07 / \text { box })\end{array}$ & 12 & 14 & 16 & 18 & 19 & 21 & 23 & 25 & 26 \\
\hline $\begin{array}{l}\text { Total } \\
\text { Delivered- } \\
\text { in Cost per } \\
\text { acre }\end{array}$ & 3,532 & 3,608 & 3,684 & 3,760 & 3,837 & 3,913 & 3,989 & 4,065 & 4,141 \\
\hline $\begin{array}{l}\text { Break-even } \\
\text { Price for } \\
\text { Fresh GF: }\end{array}$ & \multicolumn{9}{|c|}{ \$ per box } \\
\hline On-tree & 29.07 & 24.61 & 21.14 & 18.36 & 16.09 & 14.20 & 12.59 & 11.22 & 10.03 \\
\hline Delivered-in & 31.42 & 26.96 & 23.49 & 20.71 & 18.44 & 16.54 & 14.94 & 13.57 & 12.38 \\
\hline
\end{tabular}

